\title{
The "Bear Claw" Drywall Repair Clips: Bringing A New Product To Market
}

\author{
Jerrold A. Van Winter, Hood College, USA
}

\begin{abstract}
The "Bear Claw" case provides students, among several lessons, a cautionary tale of an entrepreneur taking a new product to market on their own. John DiGate obtained a patent for his product, the "Bear Claw", in 2001. The product provides a unique and effective method of repairing holes in drywall. The patent attorney working on the case was so impressed with the product that he offered to do the patent work at no charge in return for a percentage of the company. Despite some early positive successes, such as winning the Retailers Choice Award at the National Hardware Show in Chicago and having the opportunity to demonstrate the product on the QVC television network, the product has not achieved commercial success.

After reading the case, students should appreciate the effort and investment that was made in attempting to commercialize this idea. They will observe that critical steps, such as marketing research and environmental scanning, were, for the most part, ignored. By the end of the case analysis, students should develop an appreciation of the importance of key marketing concepts in launching a new product and be better prepared if faced with a similar situation later in their careers.
\end{abstract}

Keywords: Marketing; Entrepreneurship; New Product Development; Marketing Strategy; Marketing Research

\section{INTRODUCTION}

$\varnothing$

ohn DiGate had not anticipated being in this situation in 1998, when he first had the idea for the "Bear Claw". He had invented a product that filled a common home repair need, successfully patented the product and was thrilled when the product won the Retailers Choice Award at the National Hardware Show in Chicago. John even had the opportunity to demonstrate the product on QVC, a home shopping network. Based on these early successes, John was certain the product would be a major hit. However, here he was facing mounting debt and disappointing sales. What was the problem? Had he overestimated the demand for the "Bear Claw" in the marketplace or was the product not successfully reaching the market? Should he have waited longer and explored different distribution options or was first mover advantage critical for this new to the world product? John did not know the answers to those questions, but he knew he needed to figure them out soon.

\section{THE "BEAR CLAW" IDEA}

The method of repairing a hole in an interior drywall wall has not changed in decades. The hole in the drywall would be enlarged until the midway point of the studs on each side of the hole were reached. With standard wall stud spacing, this meant enlarging the hole to 16 inches, even if the original hole was only an inch or two in size. Once the hole was cut, a piece of drywall just smaller than the new hole would be cut and then inserted into the hole. The seams of the new drywall piece would then be spackled with drywall paste and, once dried, the paste would need to be sanded. This process would be repeated, if necessary, until the seams of the new piece of drywall were smooth, at which time the area could be painted to match the rest of the wall.

John, a civil engineer by trade, had always enjoyed carpentry and home repair. One day in 1998, while renovating his attic into a playroom for his children, he encountered a fist sized hole in a drywall wall. The hole was too big to be taped over and it seemed a waste to cut the hole all the way back to the studs. He thought about the 
problem for a few hours and came up with an idea for clips that would hold a piece of drywall into place in any size hole. This idea would allow him to repair the damage without having to cut back the undamaged drywall. Once the patch was in place, the repair could be finished just as before. The advantage of the clips was that the job could now be completed with less paste, less sanding, less wasted materials and a smaller hole to blend into the existing wall. John made prototype clips out of metal plumbing strap material in 2-3 hours. At that point, he knew he had come up with something special, a belief that has not changed to this day.

John named this first clip the "Delta" clip. He later worked on several different designs, as recommended by his patent attorney (see "The Patent Process" section), and preferred a version he named the "Bear Claw" (see Figure 1). While the "Bear Claw" worked in a similar manner as the Delta clip, it had two major advantages - a hole in any thickness of wall (drywall is most often sold in $1 / 2$ inch and $5 / 8$ inch thicknesses) could be repaired with a $1 / 2$ inch piece of drywall and the new clip consisted of approximately half the amount of metal as the Delta clip.

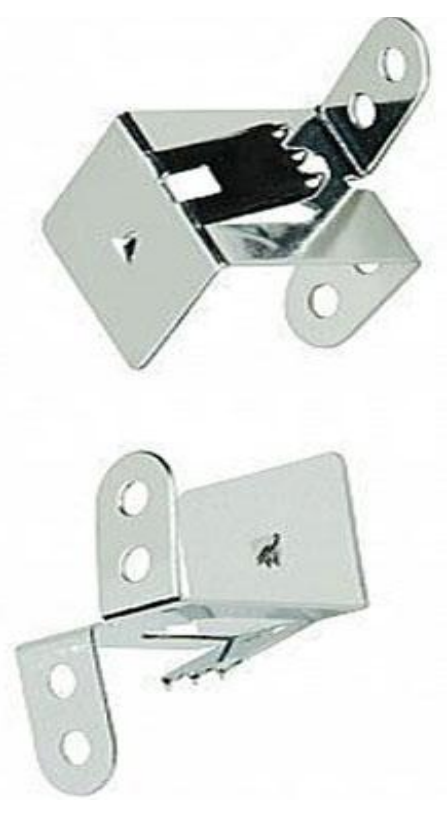

Figure 1: The "Bear Claw" Drywall Clips

\section{THE PATENT PROCESS}

John met with a patent attorney based in Washington, D.C. who was recommended to him. The patent attorney explained how companies often have attorneys and engineers that will carefully design around patents, which is why John developed several designs. The patent attorney loved the concept of the Delta clip, and later the Bear Claw. He offered to waive his legal fees for the patenting process for a percentage of the business. After several days of negotiating, John had a new, mostly silent, partner. John and his partner incorporated the business in early 1999 under the name DiGate Design, Inc.

A patent for the Delta drywall clip was received in February 2000 and a patent on the Bear Claw drywall clip was granted in April 2001.

\section{PRODUCING THE "BEAR CLAW" CLIPS}

After receiving patent approval for the Delta clip, a local machinist was contacted in March 2000 to make more polished prototypes. Initially the machinist used small hand tools that were capable of producing a limited number of clips. The machinists then proposed that he make a die set that could create thousands of clips per day, 
allowing John to produce the clips himself. The machinist started work on the machining in April 2000 and by November of the same year, John realized the project was a failure. The production quality of the clips varied and the clips were not as stiff as necessary to be effective. By the time John shut the project down, he had invested $\$ 20,000$ into machining and $\$ 16,000$ into a bagging machine that was to be used for packaging the clips.

Shortly after patent protection was obtained on the Bear Claw in April 2001, work was begun on researching alternative production options for the clips. A request for proposals was sent to several U.S. machining companies for quotes for a machine to produce the clips. The least expensive bid to produce the machinery was $\$ 27,000$ and that machinery would only be capable of producing a single size clip. The time to produce the machinery was estimated at six months. Several Chinese production companies were then contacted. The lowest cost estimate was $\$ 500$ per clip size for the company to set up the equipment for manufacturing. The time estimate for the machining was three months. Contracts were signed and deposits made with one of the Chinese companies in June 2001.

Working with a graphics expert from his engineering firm, John settled on producing two package sizes. The "Bear Claw" would be offered in quantities of eight and 50 clips. The 8-pack would consist of a clear blister pack on a cardboard card and the 50-pack would be sold in a clear clamshell pack. The first samples from China were received in November 2001 for inspection and approval. The quality of the clips and packaging was excellent. Production approval was given and an initial order for \$35,000 of "Bear Claw Clips was made in December 2001.

The first batch of clip inventory was received from the Chinese manufacturer in December 2002. The inventory was moved to a full service warehouse in York, Pennsylvania, at a cost of $\$ 150$ per month.

\section{POSITIVE PUBLIC RELATIONS}

In November 2002, DiGate Design contacted the Handyman Journal to inquire about Handyman subscribers testing the "Bear Claw" clips. The magazine agreed and samples are sent to 400 subscribers. In February 2003, the results are made public, the clips received a 97\% approval rating, and the magazine printed an article about the clips.

In April 2003, the "Bear Claw"clips were introduced for the first time at the National Hardware Show in Chicago and won the Retailers Choice Award for innovative products. In addition, the "Bear Claw" clips were selected to be covered on HGTV's show covering the National Hardware Show and were also featured on a local Baltimore news station.

\section{POTENTIAL TARGET MARKETS}

While the "Bear Claw" had the potential to be helpful to any do-it-yourself type person, John believed the key target market was trade professionals, such as electricians and plumbers. A homeowner may only need to repair drywall a few times in their lives and likely will not be aware of a product such as the "Bear Claw". Even if a small percentage of the homeowner market was aware of the product, a singular sale of a relatively inexpensive product would not lead to significant revenue. A contractor, on the other hand, may need to repair drywall several times a day. For instance, if an electrician needed to run a new electrical line along a wall, holes would need to be cut every 16 inches in the drywall so that the line can be fed through holes drilled in the wall studs. By using the "Bear Claw" drywall clips the electrician will be able to reuse the drywall pieces they removed from each hole and quickly repair the wall.

John had explored packaging the clips in quantities of 200 in reusable plastic buckets, which is the preferred packaging option for contractors. He had not yet started producing the larger packages because he was stymied as to how to reach the contractor market. He had contemplated running ads aimed at contractors in trade magazines, but the cost of running a quarter page ad in his magazine of choice was $\$ 10,000$, which was beyond the financial reach of DiGate Design. 


\section{THE SEARCH FOR STRATEGIC PARTNERS BEGINS}

John made contact with both USG (United Sates Gypsum Corporation) and Homax in December 2001 to discuss each company's interest in selling the "Bear Claw" under their names with DiGate's Design manufacturing the clips. USG sells about $30 \%$ of the wallboard in the North American market (http://www.usg.com/company/about-usg.html) and Homax is a leading supplier of DIY (do it yourself) and professional home improvement products, so they are each a good fit for the product. Samples and market forecasts are shared with both companies.

DiGate Design met with USG marketing representatives in Chicago (the location of USG's corporate headquarters) in March 2002. DiGate Design presented USG with a proposal and pricing structure for the clips. USG responded in April 2005 with a decision to pass on the proposal. USG representatives suggest that DiGate Design partner with a current USG supplier who also produces a drywall repair product. John believed that the "Bear Claw" was a clearly superior product and that the other company would have little incentive to push the "Bear Claw" over their own product, so he did not pursue the suggestion.

After being rejected by USG, discussions were opened with Homax in May 2002. Homax appeared to be very interested, and requested pricing information and clip samples to distribute to their marketing people. After negotiating on and off for five months, the decision was made for Homax and DiGate Design to go their own ways. DiGate Design was looking for a commitment that Homax was not prepared to make in the short term.

In December 2002, Digate Design started approaching local (Maryland, Virginia \& Delaware) hardware chains in an attempt to get them to carry the "Bear Claw" clips.

Discussions were opened with Orgill, Inc. in June 2003. The largest independent hardware supplier in the United States, Orgill provides wholesale, distribution and retailing services. In July 2003, Digate Design was invited to sell the "Bear Claw" to Orgill dealers. The first selling show was in Atlanta in September of that year. DiGate Design spent the month before the meeting creating packaging options and displays for the meeting. Graphic displays were ordered, along with merchandising racks with card displays showing how to use the product. Interest in the "Bear Claw" was fairly high at the September show, with over $\$ 3,000$ of clips being sold. However, the cost of the show was approximately $\$ 6,000$. At the show, John discovered that the "Bear Claw" clips were not being sold out of the Orgill warehouses and other vendors informed John that for the product to be successful, it needed to be in the warehouses. John spoke to his purchasing contact at Orgill, who said he would look into getting the clips into the warehouse. In November 2003, Orgill invited DiGate Design to sell the "Bear Claw" clips out of Orgill warehouses, which is good news. However, this was followed by disappointment when the first order for Orgill's four warehouses was very small.

In May 2004, DiGate Design decided to attend Orgill's semi-annual selling show in Florida. The goal of the show was to evaluate market interest now that the "Bear Claw" clips were in the Orgill warehouses. The Orgill sales representative showed interest and brought several of their larger chain store customers to the DiGate Design booth. The future sales potential of working with Orgill was looking up. Sales for the show increased 33\% from the first show to approximately $\$ 4,000$, but the show cost was $\$ 7,000$ to attend.

The September 2004, Orgill selling show was in Baltimore, MD, which had the advantage of being local for DiGate Design. Unfortunately, DiGate Design was given what is likely the worse location in the convention center and sales were the weakest of the three Orgill shows attended. The loss for the show was approximately $\$ 3,000$ and would have been much worse if not for the lack of travel and lodging expenses. The decision was made that trying to sell through Orgill, Inc. was a losing battle.

DiGate Design met with House Hanson, a distributor to independent hardware stores, in June 2004 to demonstrate the "Bear Claw". House Hanson was very enthusiastic about the product and agreed to carry the drywall clips. DiGate Designs attended the House Hanson selling show in Kansas City, MO, in October 2004. Sales were slow as many of the smaller store owners complained about having to buy a "whole" case, which contains (20) 8 -packs of clips for $\$ 20$. The loss for the show was approximately $\$ 3,500$ and Digate Design decided not to further pursue the independent hardware distributor market. 


\section{THE HOME DEPOT AND LOWES HARDWARE CHAINS}

The Home Depot and Lowes hardware chains are the dominant hardware retailers in the United States, so placing the "Bear Claw" in the stores of either of these chains would be a huge boost to Digate Design. The only opportunity John had to engage a representative of either organization was at a hardware show in Atlanta. Unfortunately, he was in the middle of what he believed was a productive conversation with a Home Depot buyer when he was interrupted with a question. When he turned back to continue the conversation the buyer was gone and John never saw him again. Since The Home Depot requires suppliers to deal directly with each of their over 2,200 retail locations, it would have been difficult for a small company like DiGate Design to work with the chain. Lowes has their own warehouses, making the stores more accessible to a small company such as DiGate Design. However, Digate Design has not been successful in arranging a product demonstration or meeting with Lowes.

\section{THE QVC EXPERIENCE}

DiGate Design was invited to a product review seminar at QVC's corporate headquarters in West Chester, PA, in February 2005. John demonstrated the product's ease of use at the seminar and looked forward to hearing back regarding QVC's decision which could have been the opportunity that moves the "Bear Claw" into the black. The good news - that QVC was inviting the "Bear Claw" to their product line - was received the same month. QVC stipulated that they would like a full drywall repair kit, not just the repair clips, and would like the kit to retail for approximately \$20. Packaging standards for the kit was also provided by QVC. DiGate Design got to work thinking about what should be included in the QVC drywall repair kits and a decision was made to include the following items in the kit:

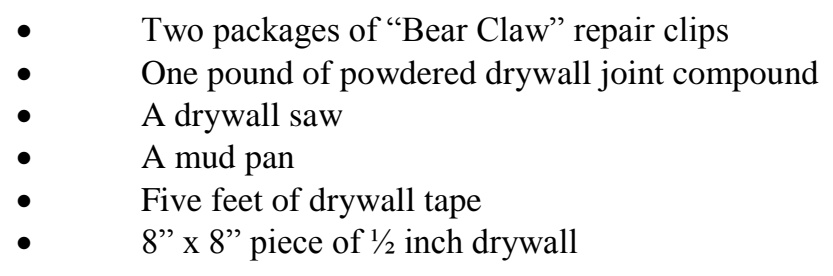

A saw table would have to be built to cut 4' x 8' drywall boards into 8" $\mathrm{x} 8$ "' squares. The saws and drywall tape were ordered from overseas and a local packaging contractor was selected to assemble and package the kits. All the items were received by June 2004. The items were packaged and 3,100 units were sent to QVC in July with air time scheduled for August.

John went on air at QVC in August to discuss and demonstrate the "Bear Claw". The presentation seemed to go well and 1,200 units were sold during the first showing. Unfortunately, QVC expected sales of at least 2,000 units during the first showing in order for a vendor to be invited back. QVC did not invite DiGate Design back for a second showing and returned the unsold kits. DiGate Design suffered a $\$ 20,000$ loss on the project.

\section{COST AND PRICING OF THE "BEAR CLAW"}

After a rocky start trying to produce their own clips, DiGate Design was very happy with their supplier in China. The quality of the clips was excellent and consistent. Orders were filled in a timely manner and the vendor even agreed to finance several large orders until DiGate Design was paid. The cost of producing a single clip is 1.5 cents. When packaged in a pack of eight, the total cost is approximately 20 cents, including the cost of the packaging. The shipping cost is almost negligible as the clips are small and relatively light. DiGate Design sells the clips to retailers for approximately $\$ 1.50$ a pack, with significant discounts available for large purchases. The suggested retail price is $\$ 2.85$, but the product is often seen in stores being sold for over $\$ 3.00$ (for example, the clips sell for $\$ 3.49$ at Fenwick Hardware store in Fenwick, Delaware). While the profit margin of up to $\$ 1.30 /$ pack appears to be fairly large, many of the orders are small and much of the profit is consumed by the labor and mailing costs of filling the orders. 


\section{PRODUCT FEEDBACK}

DiGate Design is proud that in almost 10 years of selling the "Bear Claw" drywall repair clips, not a single clip has been returned. In addition, not a single kit that was sold on QVC has been returned. The clips have been given to over a dozen contractors to use and the feedback from all has been positive. Often, when he is feeling frustrated by the lack of clip sales, John will go to his barn, where he has set up sample drywall repair walls, and use the clips. The quickness and ease of use of the clips is a continual reconfirmation to him of the important repair need they fill.

\section{NEXT MOVE}

At this point John had invested a significant portion of his family's nest egg into the "Bear Claw", with mostly disappointing financial results. He knew he needed to seriously consider his options. Should he give up on the idea altogether, despite the positive customer feedback, or should he consider other alternatives? He often wonders what he could have done differently and whether it would have made a difference.

\section{DISCUSSION QUESTIONS}

1. From the information provided in the case, how much has Digate Design invested in the "Bear Claw" to this point? Are these the total costs incurred by Digate Design and John Digate on the product? If not, please explain.

2. Complete a quick SWOT Analysis for Digate Design. What information do you believe is most important from this analysis of the company's strengths, weaknesses, opportunities and threats?

3. What strategic alternatives did John DiGate have after inventing the "Bear Claw"?

4. Based on your SWOT Analysis, what do you believe was the best strategic option for John after inventing the 'Bear Claw"?

\section{ACKNOWLEDGEMENT}

This case study was developed with the help and support of John DiGate, Digate Design, Inc.

A special thanks to the Hood College Board of Associates for the McCardell Professional Development Grant, which was awarded for the development of this case study.

\section{AUTHOR INFORMATION}

Jerrold A. Van Winter, Ph.D., assistant professor of marketing, earned a doctorate in marketing from The George Washington University, with a secondary concentration in organization behavior. His areas of interest include international marketing, services marketing and marketing strategy. Van Winter started his career in the telecommunications industry, and later served as first director of marketing and then president of a several hundred employee computer software company. He currently teaches and consults in both the marketing and management areas. E-mail: vanwinter@hood.edu 